\title{
Roncus sutikvae sp.n. (Pseudoscorpiones: Neobisiidae), a new epigean pseudoscorpion from central Dalmatia (Croatia)
}

\author{
Roncus sutikvae sp.n. (Pseudoscorpiones: Neobisiidae), новый \\ наземный можноскорпион из Џентральной Аалмаџии (Хорватия)
}

\author{
Božidar P.M. Ćurčićíc, Tonći Rađa ${ }^{2}$, Rajko N. Dimitrijević1, \\ Nikola R. Vesovićc ${ }^{1}$, Nina B. Ćurčić3 ${ }^{3}$, Srećlko B. Ćurčići ${ }^{*}$ \\ Б.П.М. Чурчич ${ }^{1 \dagger}$, Т. Раджа ${ }^{2}$, Р.Н. Аимитриевич ${ }^{1}$, Н.Р. Весович ${ }^{1}$, \\ Н.Б. Чурчич ${ }^{3}$ С.Б. Чурчич ${ }^{*}$
}

\footnotetext{
${ }^{1}$ Institute of Zoology, University of Belgrade - Faculty of Biology, Studentski Trg 16, 11000 Belgrade, Serbia; E-mail: srecko@bio.bg.ac.rs

${ }^{2}$ Špiljar Speleological Society, Varaždinska 53, 21000 Split, Croatia.

${ }^{3}$ Geographical Institute "Jovan Cvijić", Serbian Academy of Sciences and Arts, Đure Jakšića 9, 11000 Belgrade, Serbia.
}

KEY WORDS: false scorpions, new species, soil-dweller, Dinarides, Balkan Peninsula.

КЛЮЧЕВЫЕ СЛОВА: ложноскорпионы, новый вид, почвенный обитатель, Динариды, Балканский полуостров.

ABSTRACT. A new pseudoscorpion species of the genus Roncus L. Koch, 1873, Roncus sutikvae sp.n., from an epigean site (Sutikva hill, village of Mravince, near the town of Solin and the city of Split) in central Dalmatia (Croatia) is described and diagnosed. All important morphological traits of the new taxon are specified and drawn. The new pseudoscorpion species is compared with its closest congeners inhabiting the surrounding regions in Croatia. This new epigean pseudoscorpion is endemic to a small area of the Dinarides in central Dalmatia. A key to the species of Roncus known to occur in Croatia is given.

How to cite this paper: Ćurčić B.P.M., Rađa T., Dimitrijević R.N., Vesović N.R., Ćurčić N.B., Ćurčić S.B. 2021. Roncus sutikvae sp.n. (Pseudoscorpiones: Neobisiidae), a new epigean pseudoscorpion from central Dalmatia (Croatia) // Arthropoda Selecta. Vol.30. No.2. P.205-215. doi: 10.15298/arthsel.30.2.07

РЕЗЮМЕ. Даны описание и диагноз нового ложноскорпиона из рода Roncus L. Koch, 1873, Roncus sutikvae sp.n., из наземного биотопа (холм Сутиква, деревня Мравинце близ городов Солин и Сплит) в Центральной Далмации (Хорватия). Все важные морфологические черты нового таксона определены и проиллюстрированы. Новый вид ложноскорпионов сравнивается с ближайшими членами рода, населяющими окружающие районы Хорватии. Этот новый наземный ложноскорпион — эндемик небольшой территории Динарских гор в Центральной Далмации. Дан ключ для видов Roncus, известных пока из Хорватии.

\section{Introduction}

The genus Roncus L. Koch, 1873 is one of the largest in the family Neobisiidae, presently comprising about 140 species [Harvey, 2013], both cave-dwelling and epigean [Gabbutt, Vachon, 1967; Ćurčić et al., 2021], which range from the USA in the west through Europe (except its northern part), North Africa, the Caucasus, and the Near East to northeastern Iran in the east [Ćurčić et al., 1992; Harvey, 2013; Latifi et al., 2020]. The genus Roncus is most diverse in the Balkans (it is somewhat less diverse on the Apennine and Iberian peninsulas), especially in the Dinaric Mountains, where the proportion of relict troglobites is especially high [Ćurčić, 1988; Gardini, 2000; Ćurčić et al., 2004, 2020; Ozimec, 2004; Henderickx, Zaragoza, 2009; Mahnert, Gardini, 2014; Ćurčić, Dimitrijević, 2016].

Knowledge of the taxonomy of Roncus at the specific level is insufficient [Ćurčić, 1992]. Traditional taxonomy using setation and a restricted number of morphometric and meristic characters (e.g., pedipalp morphometry, chelal dentition, setation of the carapax and opisthosoma, etc.) is not adequate in attempting to identify epigean species and can be employed only to distinguish between relict or highly specialized species [Ćurčić, 1992; Zaragoza, Štáhlavský, 2008]. Newer taxonomy utilizing features not previously considered (characteristics of the legs, including measurements and ratios of legs $\mathrm{I}$ and $\mathrm{IV}$, shape of the claws and subterminal setae, disposition of tactile setae on leg IV, anatomy of the genital apparatus, etc.) is more comprehensive [Zaragoza, Št'áhlavský, 2008]. The chelal microsetal pattern in Roncus is helpful in distinguishing 
both species groups and individual species [Gardini, 1983; Gardini, Rizzerio, 1985, 1986; Henderickx, Zaragoza, 2005]. Thus, based on the presence/absence of microsetae proximal to trichobothria $e b$ and $e s b$, one can distinguish the species group of Roncus lubricus L. Koch, 1873 (carrying a few microsetae proximal to $e b$ and $e s b$ ) and a complex of other species groups of Roncus (in which microsetae placed proximal to $e b$ and $e s b$ are missing). Within the latter complex, numerous species groups are recognized, but only several of those are officially established [Gardini, 1982; Gardini, Rizzerio, 1987; Ćurčić, 1992]. Two informal groups of species are identified in Roncus: roncoid (with epigean facies) [Zaragoza et al., 2007] and parablothroid (cave-dwelling in appearance) [Gardini, 1982]. Data on Roncus distribution patterns are scant. Ćurčić [1992] commented that $R$. lubricus might belong to a group of species distributed over the western and southwestern parts of Europe, while most Balkan taxa form another group, inhabiting its eastern and southeastern parts and perhaps Southwest Asia as well. One of the tasks of investigators in the future is to reveal the main distribution patterns of the genus across its entire range.

The diversity of the Balkan pseudoscorpion fauna varies from country to country [Christophoryová, Jablonski, 2017; Christophoryová et al., 2018; Novák et al., 2019; Ćurčić et al., 2020]. The greatest number of pseudoscorpion taxa on the Balkan Peninsula has been reported for Greece (123 species and 22 subspecies) [Harvey, 2013; Mahnert, Gardini, 2014] and Croatia (122 species and 22 subspecies) [Ozimec, 2004; Ćurčić et al., 2012a, b, c, d, e, f, 2013a, b, c, d, 2014a, b, 2015, 2021; Harvey, 2013; Dimitrijević, Rađa, 2016]. The territory of Croatia is currently known to be inhabited by a total of 16 species of Roncus, 12 of which are cave-dwelling, while the remaining four live in habitats other than caves (soil and leaf litter) [Ćurčić, 1988; Ćurčić et al., 2012d, e, f, 2014a, 2021; Harvey, 2013]. Roncus taxa in Croatia are chiefly distributed in the Dinarides and are stenoendemics in most cases [Ćurčić, 1988; Harvey, 2013].

As certain karstic areas in Croatia (especially in Dalmatia) still remain weakly investigated or even unexplored, one may expect further findings of new pseudoscorpion species in these areas in the future.

A field trip in central Dalmatia (Croatia) conducted by the Špiljar Speleological Society (Split, Croatia) in 2014 resulted in the discovery of a small sample of a new pseudoscorpion species, whose description and diagnosis are given in the present paper.

\section{Material and methods}

A sample of neobisiid pseudoscorpions was collected by hand under stones at an epigean site (on a hillside of a rocky terrain) in central Dalmatia (Croatia). The pseudoscorpion specimens were studied in the laboratory of the Institute of Zoology, University of Belgrade - Faculty of Biology, Belgrade, Serbia. They were first carefully dissected and placed on microscope slides in glycerol, then measured and figured, and finally fixed in a medium consisting of Canada balsam and xylol. Important morphological traits were analysed using a Carl Zeiss - Axioskop 40 microscope with a drawing attachment.

Setal designations follow Beier [1963] and Ćurčić [1988].

The following abbreviations are used in the manuscript: AUT - Austria; BIH - Bosnia and Herzegovina; F female; FF - females; H - holotype; HUN - Hungary; ITA - Italy; IZFB - collection of the Institute of Zoology, University of Belgrade - Faculty of Biology, Belgrade, Serbia; M - male; MNE — Montenegro; NHMS — collection of the Natural History Museum in Split, Croatia; P paratype; $\mathrm{R}$ - range of total measurements performed; SRB - Serbia; SVN - Slovenia; TS — tactile seta.

\section{Taxonomy}

Family Neobisiidae Chamberlin, 1930

Genus Roncus L. Koch, 1873

\section{Roncus sutikvae sp.n.}

Fig. 1.

TYPE MATERIAL. H F labeled as follows: "Sutikva hill, $43^{\circ} 32^{\prime} 01.7^{\prime \prime} \mathrm{N} 16^{\circ} 30^{\prime} 27.2^{\prime \prime} \mathrm{E}$, village of Mravince, near the town of Solin and the city of Split, central Dalmatia, Croatia, $21^{\text {st }}$ September 2014, leg. T. Rađa" (NHMS-2015-1) (white label, printed) / HOLOTYPUS Roncus sutikvae sp.n. B. Curčić \& Dimitrijević det. 2015 (red label, printed); one P F, same data as for H (IZFB-20151) (white label, printed) / PARATYPUS Roncus sutikvae sp.n. B. Ćurčić \& Dimitrijević det. 2015 (red label, printed).

DESCRIPTION. Body colour brownish. Dorsal side of carapace reaching maximum breadth at level behind "ocular" setal row, longer than broad (Fig. 1h; Table 1). A single pair of distinct eyes developed (Fig. 1h). Anterior carapacal margin slightly broader than posterior one; carapace resembling a regular trapezium (Fig. 1h). Epistome triangular, apically rounded (Fig. 1h). Carapace carrying 28 or 29 setae arranged in five rows: $4-5$ in anterior row, 7-8 in ocular row, 2 in median row, 6 in intermedian row, and 8-9 in posterior row (Fig. 1h). No preocular microsetae developed in either preocular recess.

Genital area. Setal formula of opisthosomal tergites I-X: 8-11-11-11-12-11-10-10-10-10 (in $\mathrm{H} \mathrm{F}$ ) and 9-11-11-1113-12-11-11-11-10 (in P F). In H F, opisthosomal sternite II carrying a cluster of 11 setae; sternite III with 14 setae and four suprastigmatic microsetae on each side; sternite IV with 13 setae along its posterior margin and three microsetae along each stigma; sternite V with 13 setae; sternite VI with 15 setae; sternite VII with 14 setae; sternite VIII with 14 setae; sternite IX with 14 setae; and sternite $X$ with 13 setae (Fig. 1g). In P F, the setal formula of opisthosomal sternites II-X is as follows: 12-14-12-14-16-16-15-14-12. P F with three suprastigmal microsetae on both opisthosomal sternites III and IV.

Galea resembling a tiny sclerotic knob (Fig. 1a). On fixed cheliceral finger, teeth on blade somewhat longer medially than distally or proximally; $\mathrm{H} \mathrm{F}$ and P F carrying 14 and 15 such teeth, respectively (Fig. 1a). Movable cheliceral finger carrying a single seta, fixed cheliceral finger with six long setae. Flagellum carrying nine (in $\mathrm{H} \mathrm{F}$ ) or eight (in P F) pinnate blades (Figs 1e and 1f).

Pedipalpal articles somewhat elongate; a small area of granulations present both on whole interior side of femur 


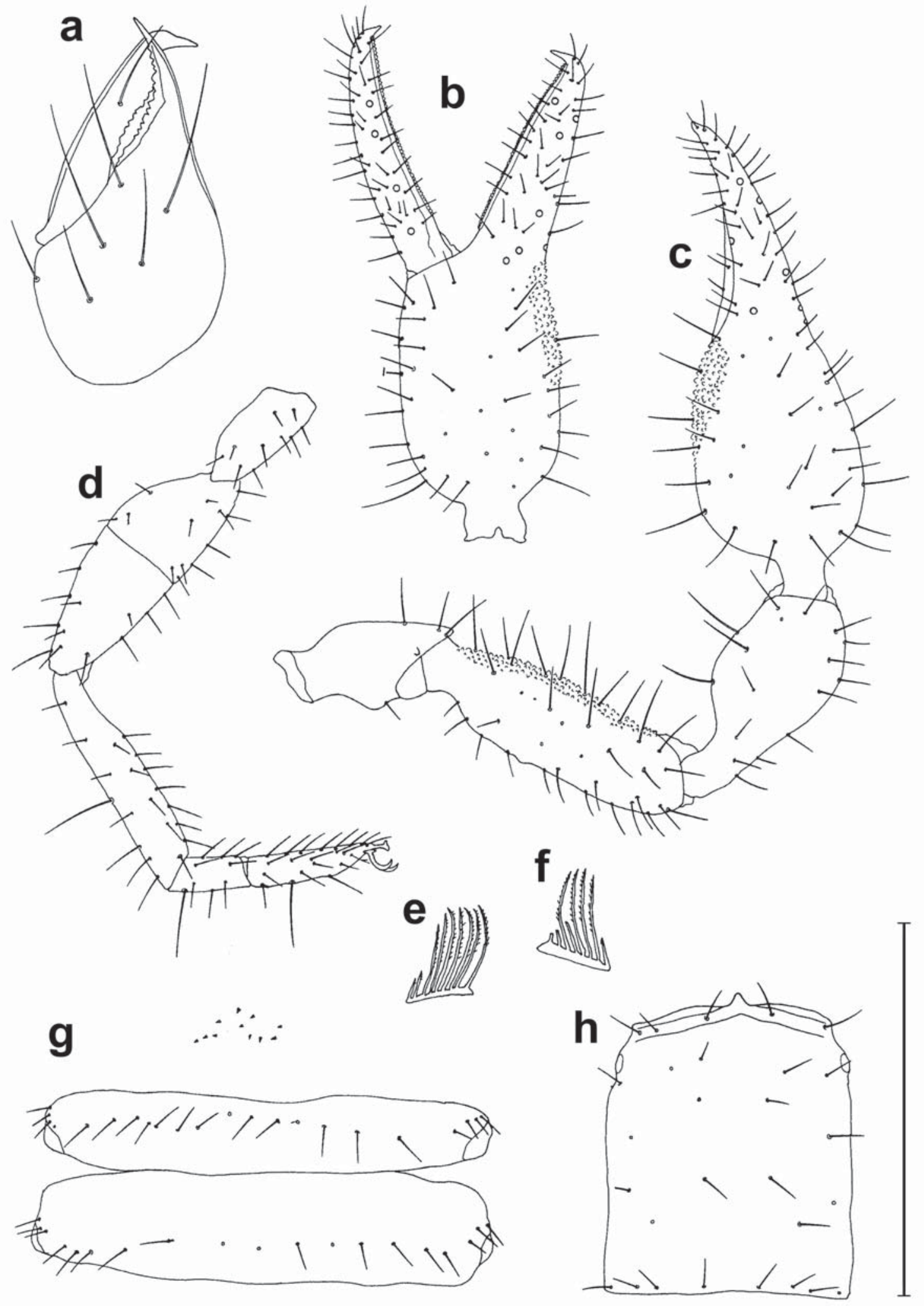

Fig. 1. Roncus sutikvae sp.n., H F (a-e, g and h) and P F (f): a — chelicera; b - pedipalpal chelal palm; c - pedipalp; $\mathrm{d}$ - leg IV; e and $\mathrm{f}$ - flagella; $\mathrm{g}$ - genital area; $\mathrm{h}$ - carapace. Scales: $0.50 \mathrm{~mm}$ (a and e-g) and $0.25 \mathrm{~mm}(\mathrm{~b}-\mathrm{d}$ and $\mathrm{h}$ ).

Рис. 1. Roncus sutikvae sp.n., голотип-самка (a-e, g и h) и паратип-самка (f): a - хелицера; b - рука хелы педипальпы; c педипальпа; d - нога IV; e и f - жгутики; g — генитальное поле; $\mathrm{h}$ - карапакс. Масштаб: 0,50 мм (a и e-g) и 0,25 мм (b-d и h). 
Table 1. Linear measurements (in millimetres) and morphometric ratios in Roncus sutikvae sp.n. and related congeneric species (modified after Gardini, Rizzerio [1985], Ćurčić [1988], and Ćurčić et al. [2010, 2012e, 2013c, 2021]). Abbreviations are given in the Material and methods section.

Таблица 1. Линейные размеры (в мм) и морфометрические соотношения у Roncus sutikvae sp.n. и родственных видов (с изменениями по: Gardini, Rizzerio [1985], Ćurčić [1988] и Ćurčić et al. [2010, 2012e, 2013c, 2021]). Сокращения даны в разделе Материал и методы.

\begin{tabular}{|c|c|c|c|c|c|c|c|}
\hline Species & $\begin{array}{l}\text { R. sutikvae } \\
\text { sp.n. }\end{array}$ & R. diocletiani & R. italicus & R. trojanicus & R. almissae & R. ladestani & R. navalia \\
\hline Character/sex & $\mathrm{FF}$ & $\mathrm{F}$ & M F & $\mathrm{F}$ & M F & M & M F \\
\hline \multicolumn{8}{|l|}{ Body } \\
\hline Length (1) & $2.91-3.12$ & 3.115 & $2.35-2.50$ & 4.445 & $3.09-4.00$ & 3.22 & $2.30-2.975$ \\
\hline \multicolumn{8}{|l|}{ Carapace } \\
\hline Length (2) & $0.75-0.77$ & 0.815 & $0.725-0.82$ & 1.10 & $0.88-0.97$ & 0.805 & $0.72-0.87$ \\
\hline Breadth (2a) & $0.61-0.63$ & 0.61 & $0.49-0.60$ & 0.95 & $0.72-0.805$ & 0.69 & $0.59-0.64$ \\
\hline Ratio $2 / 2 \mathrm{a}$ & 1.23 & 1.34 & $1.37-1.51$ & 1.16 & $1.20-1.22$ & 1.17 & $1.22-1.36$ \\
\hline \multicolumn{8}{|l|}{ Opisthosoma } \\
\hline Length & $2.14-2.37$ & 2.30 & - & 3.57 & $2.21-3.03$ & 2.415 & $1.58-2.11$ \\
\hline \multicolumn{8}{|l|}{ Chelicerae } \\
\hline Length (3) & $0.47-0.49$ & 0.48 & $0.435-0.515$ & 0.59 & $0.51-0.55$ & 0.53 & $0.44-0.51$ \\
\hline Breadth (4) & $0.24-0.25$ & 0.25 & $0.22-0.275$ & 0.33 & $0.275-0.295$ & 0.27 & $0.24-0.275$ \\
\hline $\begin{array}{l}\text { Length of } \\
\text { movable } \\
\text { finger (5) }\end{array}$ & $0.305-0.315$ & 0.34 & $0.30-0.365$ & 0.40 & $0.36-0.40$ & 0.38 & $0.305-0.37$ \\
\hline Ratio 3/5 & $1.49-1.61$ & 1.41 & $1.41-1.485$ & 1.475 & $1.375-1.42$ & 1.39 & $1.38-1.44$ \\
\hline Ratio 3/4 & 1.96 & 1.92 & $1.80-2.00$ & 1.79 & $1.85-1.86$ & 1.96 & $1.83-1.85$ \\
\hline \multicolumn{8}{|l|}{ Pedipalps } \\
\hline $\begin{array}{l}\text { Length with } \\
\text { coxa (6) }\end{array}$ & $3.60-3.72$ & 3.98 & - & 6.895 & $4.30-4.825$ & 4.29 & $3.765-4.51$ \\
\hline Ratio 6/1 & $1.19-1.24$ & 1.28 & - & 1.48 & $1.21-1.39$ & 1.33 & $1.515-1.64$ \\
\hline $\begin{array}{l}\text { Length of } \\
\text { coxa }\end{array}$ & $0.55-0.57$ & 0.60 & - & 0.84 & $0.61-0.68$ & 0.60 & $0.57-0.58$ \\
\hline $\begin{array}{l}\text { Length of } \\
\text { trochanter }\end{array}$ & $0.44-0.47$ & 0.49 & $0.465-0.54$ & 0.665 & $0.54-0.56$ & 0.53 & $0.49-0.52$ \\
\hline $\begin{array}{l}\text { Length of } \\
\text { femur (7) }\end{array}$ & 0.78 & 0.835 & $0.80-0.89$ & 1.26 & $0.815-1.00$ & 0.92 & $0.79-1.18$ \\
\hline $\begin{array}{l}\text { Breadth of } \\
\text { femur (8) }\end{array}$ & 0.23 & 0.24 & $0.22-0.27$ & 0.30 & $0.26-0.305$ & 0.24 & $0.24-0.25$ \\
\hline Ratio $7 / 8$ & 3.39 & 3.48 & $3.20-3.68$ & 4.20 & $3.13-3.28$ & 3.83 & $3.29-4.72$ \\
\hline Ratio 7/2 & $1.01-1.02$ & 1.02 & $1.06-1.14$ & 1.145 & $0.93-1.03$ & 1.14 & $1.10-1.36$ \\
\hline $\begin{array}{l}\text { Length of } \\
\text { tibia } \\
\text { (patella) (9) }\end{array}$ & 0.64 & 0.71 & $0.645-0.73$ & 0.96 & $0.75-0.815$ & 0.75 & $0.55-0.70$ \\
\hline $\begin{array}{l}\text { Breadth of } \\
\text { tibia } \\
\text { (patella) } \\
(10) \\
\end{array}$ & $0.285-0.305$ & 0.315 & $0.28-0.36$ & 0.40 & $0.34-0.36$ & 0.34 & $\begin{array}{c}0.295- \\
0.305\end{array}$ \\
\hline Ratio 9/10 & $2.10-2.245$ & 2.25 & $2.02-2.30$ & 2.40 & $2.205-2.26$ & 2.205 & $1.86-2.295$ \\
\hline $\begin{array}{l}\text { Length of } \\
\text { chela (11) }\end{array}$ & $1.17-1.28$ & 1.345 & $1.35-1.52$ & 1.88 & $1.585-1.77$ & 1.49 & $1.355-1.54$ \\
\hline $\begin{array}{l}\text { Breadth of } \\
\text { chela (12) }\end{array}$ & $0.45-0.46$ & 0.47 & $0.39-0.53$ & 0.62 & $0.52-0.58$ & 0.48 & $0.43-0.49$ \\
\hline Ratio 11/12 & $2.54-2.84$ & 2.86 & $2.87-3.46$ & 3.03 & 3.05 & 3.10 & $3.14-3.15$ \\
\hline $\begin{array}{l}\text { Length of } \\
\text { chelal palm } \\
\text { (13) }\end{array}$ & $0.67-0.71$ & 0.69 & $0.675-0.86$ & 0.91 & $0.805-0.87$ & 0.72 & $0.63-0.73$ \\
\hline Ratio 13/12 & $1.49-1.54$ & 1.47 & $1.60-1.73$ & 1.47 & $1.50-1.55$ & 1.50 & $1.435-1.49$ \\
\hline $\begin{array}{l}\text { Length of } \\
\text { chelal finger } \\
\text { (14) }\end{array}$ & $0.61-0.63$ & 0.65 & $0.76-0.85$ & 0.97 & $0.78-0.90$ & 0.77 & $0.73-0.805$ \\
\hline Ratio $14 / 13$ & $0.89-0.92$ & 0.94 & $0.96-1.12$ & 1.065 & $0.97-1.03$ & 1.07 & $1.10-1.16$ \\
\hline
\end{tabular}


Table 1 (continued). Таблица 1 (продолжение).

\begin{tabular}{|c|c|c|c|c|c|c|c|}
\hline Species & $\begin{array}{c}\text { R. sutikvae } \\
\text { sp.n. }\end{array}$ & R. diocletiani & R. italicus & R. trojanicus & R. almissae & R. ladestani & R. navalia \\
\hline Character/sex & FF & $\mathrm{F}$ & $\mathrm{MF}$ & $\mathrm{F}$ & M F & $\mathrm{M}$ & M F \\
\hline \multicolumn{8}{|l|}{ Leg IV } \\
\hline Total length & $2.535-2.595$ & 2.71 & - & 3.93 & $2.975-3.265$ & 3.11 & $2.545-2.95$ \\
\hline $\begin{array}{l}\text { Length of } \\
\text { coxa }\end{array}$ & $0.38-0.41$ & 0.43 & - & 0.61 & $0.39-0.44$ & 0.46 & $0.41-0.48$ \\
\hline $\begin{array}{l}\text { Length of } \\
\text { trochanter } \\
\text { (15) }\end{array}$ & $0.295-0.315$ & 0.34 & 0.295 & 0.47 & $0.36-0.42$ & 0.38 & $0.33-0.36$ \\
\hline $\begin{array}{l}\text { Breadth of } \\
\text { trochanter } \\
(16)\end{array}$ & $0.14-0.15$ & 0.16 & 0.135 & 0.21 & 0.18 & 0.17 & 0.17 \\
\hline Ratio 15/16 & $2.10-2.11$ & 2.125 & 2.18 & 2.24 & $2.00-2.33$ & 2.235 & $1.94-2.12$ \\
\hline $\begin{array}{l}\text { Length of } \\
\text { femur }+ \\
\text { patella (17) }\end{array}$ & $0.69-0.71$ & 0.74 & $0.71-0.79$ & - & $0.815-0.91$ & 0.845 & $0.67-0.80$ \\
\hline $\begin{array}{l}\text { Breadth of } \\
\text { femur }+ \\
\text { patella (18) }\end{array}$ & $0.23-0.24$ & 0.26 & $0.21-0.295$ & - & $0.33-0.35$ & 0.285 & $0.26-0.275$ \\
\hline Ratio 17/18 & $2.96-3.00$ & 2.85 & $2.68-3.38$ & - & $2.33-3.76$ & 2.96 & $2.46-2.91$ \\
\hline $\begin{array}{l}\text { Length of } \\
\text { tibia (19) }\end{array}$ & $0.62-0.63$ & 0.63 & $0.615-0.73$ & 0.97 & $0.77-0.855$ & 0.74 & $0.58-0.68$ \\
\hline $\begin{array}{l}\text { Breadth of } \\
\text { tibia }(20)\end{array}$ & $0.11-0.13$ & 0.12 & $0.12-0.15$ & 0.16 & 0.15 & 0.16 & $0.12-0.13$ \\
\hline Ratio $19 / 20$ & $4.85-5.64$ & 5.25 & $4.60-6.04$ & 6.06 & $5.13-5.70$ & 4.625 & $4.83-5.23$ \\
\hline $\begin{array}{l}\text { Length of } \\
\text { metatarsus } \\
(21)\end{array}$ & $0.20-0.21$ & 0.21 & $0.21-0.245$ & 0.34 & $0.22-0.24$ & 0.285 & $0.24-0.25$ \\
\hline $\begin{array}{l}\text { Breadth of } \\
\text { metatarsus } \\
(22)\end{array}$ & $0.08-0.09$ & 0.09 & $0.085-0.11$ & 0.12 & 0.11 & 0.10 & 0.10 \\
\hline Ratio $21 / 22$ & $2.33-2.50$ & 2.33 & $2.22-2.47$ & 2.83 & $2.00-2.18$ & 2.85 & $2.40-2.50$ \\
\hline $\begin{array}{l}\text { Length of } \\
\text { tarsus }(23)\end{array}$ & $0.33-0.34$ & 0.36 & $0.37-0.41$ & 0.48 & $0.40-0.42$ & 0.40 & $0.315-0.38$ \\
\hline $\begin{array}{l}\text { Breadth of } \\
\text { tarsus (24) }\end{array}$ & $0.07-0.08$ & 0.08 & $0.08-0.10$ & 0.11 & 0.10 & 0.09 & $0.08-0.10$ \\
\hline Ratio $23 / 24$ & $4.71-4.75$ & 4.50 & $4.05-4.82$ & 4.36 & $4.00-4.20$ & 4.44 & $3.15-4.75$ \\
\hline $\begin{array}{l}\text { TS ratio - } \\
\text { tibia }\end{array}$ & $0.56-0.59$ & 0.60 & $0.58-0.66$ & 0.57 & $0.595-0.85$ & 0.55 & $0.52-0.54$ \\
\hline $\begin{array}{l}\text { TS ratio - } \\
\text { metatarsus }\end{array}$ & $0.15-0.19$ & 0.19 & 0.19 & 0.20 & $0.17-0.23$ & 0.21 & $0.125-0.20$ \\
\hline $\begin{array}{l}\text { TS ratio - } \\
\text { tarsus }\end{array}$ & $0.24-0.31$ & 0.31 & 0.31 & 0.385 & $0.38-0.39$ & 0.38 & $0.30-0.42$ \\
\hline
\end{tabular}

and on interior side of chela distally (Figs 1b and 1c). Trochanter and tibia smooth, devoid of any granulations.

Fixed chelal finger carrying 60 (in H F) and 57 (in P F) small teeth, close-set and slightly rounded.

Forty-nine teeth present on movable chelal finger in $\mathrm{H}$ F, 52 present on it in P F (Fig. 1b). Distalmost and proximalmost teeth smaller than others (Fig. 1b). Apex of pedipalpal coxa with four long setae.

Some morphological structures (pedipalpal lyrifissures, nodus ramosus, micropores on the pedipalpal patellar and chelal pedicel, more detailed structure of the pedipalpal coxa, features of the genital apparatus) could not be studied due to the specimens' condition.

Trichobothriotaxy. Four trichobothria present on movable pedipalpal finger, eight on fixed chelal finger. Disposition of different trichobothria as in Fig. 1b. Trichobothria $e b, e s b$ and $i b$ on finger base; it, et and est on finger top.
Trichobothrium it closer to est than to et. No microsetae proximal to $e b$ and $e s b$, but four microsetae present distal to $e b$ and $e s b$. Distance $s t-s b$ longer than distance $b-s b$; distance $t$-st shorter than $b$-sb or $s t-s b$.

Leg IV. Tibia, metatarsus and tarsus each carrying a single tactile seta (Fig. 1d). Tactile seta ratio of tibia exceeding 0.50 (a single long tactile seta in distal half of this podomere) (Table 1). Each tactile seta on metatarsus and tarsus in proximal fifth and third of the relevant podomere, respectively.

Linear measurements and morphometric ratios of different morphological structures are presented in Table 1.

ETYMOLOGY. After Sutikva hill, its type locality.

DISTRIBUTION. The new pseudoscorpion species is currently known only from its type locality, i.e., Sutikva hill, village of Mravince, near the town of Solin and the city of Split, central Dalmatia, Croatia (Fig. 2). 


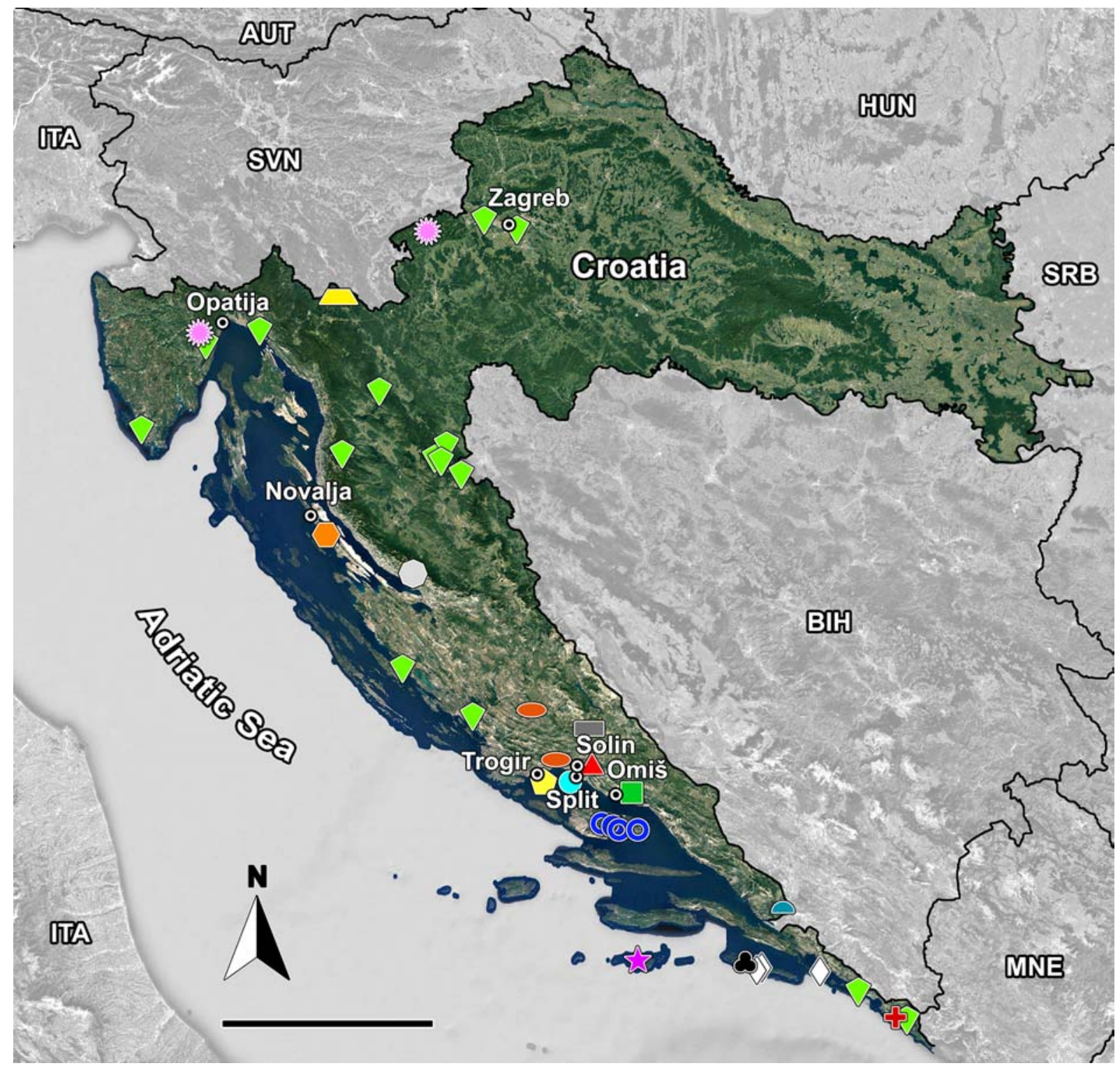

Fig. 2. Distribution of the genus Roncus in Croatia: black trefoil $-R$. meledae; brown ellipse $-R$. podaga; dark blue ring $-R$. insularis; gold trapezium $-R$. stussineri; green square $-R$. almissae; grey rectangle $-R$. pripegala; lime deltoid $-R$. lubricus; maroon cross $-R$. ragusae; orange hexagon $-R$. navalia; pink sun $-R$. italicus; purple star $-R$. ladestani; red triangle $-R$. sutikvae sp.n.; silver octagon $-R$. argyrunti; teal semicircle $-R$. narentae; turquoise circle $-R$. diocletiani; white rhombus $-R$. anophthalmus; yellow pentagon $-R$. trojanicus. Scale: $100 \mathrm{~km}$. Abbreviations are given in the Material and methods section.

Рис. 2. Распространение рода Roncus в Хорватии: черный трилистник $-R$. meledae; коричневый эллипс - R. podaga; темносинее кольцо $-R$. insularis; золотая трапеция $-R$. stussineri; зелёный квадрат $-R$. almissae; серый прямоугольник $-R$. pripegala; светло-зелёный дельтоид $-R$. lubricus; каштановый крест $-R$. ragusae; оранжевый шестиугольник $-R$. navalia; розовое солнце $-R$. italicus; лиловая звезда $-R$. ladestani; красный треугольник $-R$. sutikvae sp.n.; серебряный восьмиугольник $R$. argyrunti; сине-зелёный полукруг $-R$. narentae; бирюзовый круг $-R$. diocletiani; белый ромб $-R$. anophthalmus; жёлтый пятиугольник $-R$. trojanicus. Масштаб 100 км. Сокращения даны в разделе Материал и методы.

DIFFERENTIAL DIAGNOSIS. The new species clearly differs from all currently known epigean and hypogean congeners from Croatia, most of which inhabit Dalmatia. It is phenetically and geographically closest to Roncus diocletiani B. Curčić, Dimitrijević et Rađa, 2008, from Marasovića, southern slope of Marjan hill, city of Split; R. italicus (Simon, 1896), from Mt. Učka, near the town of Opatija, Istria, and the Žumberak - Samoborsko Gorje Nature Park, close to the city of Zagreb, northwestern Croatia (distributed in Italy,
Slovenia, and Croatia); R. trojanicus B. Ćurčić, 1988, from the Baretina Špilja (= Grota) Cave, village of Okrug Gornji, near the town of Trogir, island of Čiovo; R. almissae B. Ćurčić, Rađa, S. Ćurčić et N. Ćurčić, 2010, from the village of Podašpilje, northern slope of Mt. Omiška Dinara, near the town of Omiš; R. ladestani Dimitrijević et B. Ćurčić, 2021, from the Jama Višje Zađa (= Jama za Zle Poje) Pit, island of Lastovo; and $R$. navalia B. Ćurčić et Rađa, 2012, from the Ivča Jama Pit, near the town of Novalja, island of Pag 
(sharing the presence of one pair of eyes and of granulations on pedipalpal articles, as well as the absence of microsetae situated proximal to trichobothria $e b$ and $e s b$, at least in females). It differs from its close congeners in carapacal length (R FF $0.75-0.77 \mathrm{~mm} v s .0 .815 \mathrm{~mm}$ in $\mathrm{F} R$. diocletiani vs. $1.10 \mathrm{~mm}$ in F R. trojanicus vs. R $0.88-0.97 \mathrm{~mm}$ in $\mathrm{M} \mathrm{F}$ $R$. almissae vs. $0.805 \mathrm{~mm}$ in $\mathrm{M}$ R. ladestani); the carapacal length to breadth ratio (FF $1.23 v s .1 .35$ in F R. diocletiani vs. R 1.37-1.51 in M F R. italicus vs. 1.16 in F R. trojanicus vs. 1.17 in $\mathrm{M} R$. ladestani); cheliceral length (R FF 0.47 $0.49 \mathrm{~mm} v s .0 .59 \mathrm{~mm}$ in F R. trojanicus vs. R $0.51-0.55 \mathrm{~mm}$ in M F R. almissae vs. $0.53 \mathrm{~mm}$ in M R. ladestani); the cheliceral length to breadth ratio (FF $1.96 v s .1 .92$ in F $R$. diocletiani vs. 1.79 in $\mathrm{F} R$. trojanicus vs. $\mathrm{R} 1.85-1.86$ in $\mathrm{M}$ $\mathrm{F} R$. almissae vs. $\mathrm{R} 0.83-0.85 \mathrm{~mm}$ in $\mathrm{M} \mathrm{F} R$. navalia); cheliceral movable finger length ( R FF $0.305-0.315 \mathrm{~mm} v s$. $0.34 \mathrm{~mm}$ in $\mathrm{F} R$. diocletiani vs. $0.40 \mathrm{~mm}$ in $\mathrm{F} R$. trojanicus vs. R $0.36-0.40$ in M F R. almissae vs. $0.38 \mathrm{~mm}$ in $\mathrm{M} R$. ladestani); the cheliceral length to cheliceral movable finger length ratio (R FF 1.49-1.61 vs. 1.41 in F $R$. diocletiani vs. $\mathrm{R} 1.375-1.42$ in M F $R$. almissae vs. 1.39 in M R. ladestani vs. R 1.38-1.44 in M F R. navalia); pedipalpal length (R FF $3.60-3.72 \mathrm{~mm}$ vs. $3.98 \mathrm{~mm}$ in $\mathrm{F} R$. diocletiani vs. $6.895 \mathrm{~mm}$ in F $R$. trojanicus vs. $\mathrm{R} 4.30-4.825 \mathrm{~mm}$ in M F $R$. almissae vs. $4.29 \mathrm{~mm}$ in $\mathrm{M}$ R. ladestani vs. $\mathrm{R} 3.765-4.51 \mathrm{~mm}$ in $\mathrm{M} \mathrm{F}$ $R$. navalia); pedipalpal femur length (FF $0.78 \mathrm{~mm} v s .0 .835$ $\mathrm{mm}$ in $\mathrm{F} R$. diocletiani vs. $\mathrm{R} 0.80-0.89 \mathrm{~mm}$ in $\mathrm{M} \mathrm{F} R$. italicus vs. $1.26 \mathrm{~mm}$ in $\mathrm{F}$ R. trojanicus vs. $\mathrm{R} 0.815-1.00 \mathrm{~mm}$ in M F $R$. almissae vs. $0.92 \mathrm{~mm}$ in M $R$. ladestani); the pedipalpal femur length to breadth ratio (FF 3.39 vs. 3.48 in F R. diocletiani vs. 4.20 in F R. trojanicus vs. R 3.13-3.28 in M F R. almissae vs. 3.83 in M $R$. ladestani); the pedipalpal femur length to carapace length ratio (R FF 1.01-1.02 vs. R 1.06-1.14 in M F R. italicus vs. 1.145 in F $R$. trojanicus vs. 1.14 in M $R$. ladestani vs. R $1.10-1.36$ in M F $R$. navalia); pedipalpal tibia length (FF $0.64 \mathrm{~mm} v s .0 .71 \mathrm{~mm}$ in F $R$. diocletiani vs. $0.96 \mathrm{~mm}$ in $\mathrm{F} R$. trojanicus vs. R $0.75-0.815$ $\mathrm{mm}$ in M F R. almissae vs. $0.75 \mathrm{~mm}$ in M R. ladestani); pedipalpal chela length (R FF 1.17-1.28 mm vs. $1.345 \mathrm{~mm}$ in $\mathrm{F} R$. diocletiani vs. $\mathrm{R} 1.35-1.52 \mathrm{~mm}$ in $\mathrm{M} \mathrm{F} R$. italicus $v$ s. $1.88 \mathrm{~mm}$ in F R. trojanicus vs. R $1.585-1.77 \mathrm{~mm}$ in M F $R$. almissae vs. $1.49 \mathrm{~mm}$ in $\mathrm{M}$ R. ladestani vs. $1.355-1.54 \mathrm{~mm}$ in M F R. navalia); the pedipalpal chela length to breadth ratio (R FF 2.54-2.84 vs. R 2.87-3.46 in M F R. italicus vs. 3.03 in F R. trojanicus vs. 3.05 in M F R. almissae vs. 3.10 in M R. ladestani vs. R 3.14-3.15 in M F $R$. navalia); length of leg IV (R FF 2.535-2.595 mm vs. $2.71 \mathrm{~mm}$ in F $R$. diocletiani vs. $3.93 \mathrm{~mm}$ in $\mathrm{F}$ R. trojanicus vs. R 2.975-3.265 $\mathrm{mm}$ in M F R. almissae vs. $3.11 \mathrm{~mm}$ in M R. ladestani); the femur + patella of leg IV length to breadth ratio (R FF 2.963.00 vs. 2.85 in F $R$. diocletiani vs. $\mathrm{R} 2.33-2.76$ in $\mathrm{M} \mathrm{F} R$. almissae vs. R 2.46-2.91 in M F R. navalia); the tarsus of leg IV length to breadth ratio (R FF 4.71-4.75 vs. 4.50 in F $R$. diocletiani vs. 4.36 in $\mathrm{F} R$. trojanicus vs. $\mathrm{R} 4.00-4.20$ in M F R. almissae vs. 4.44 in M $R$. ladestani); disposition and degree of development of granulations on pedipalpal articles (trochanter with no granulations, femur with a small area of granulations on its entire interior side, chela with a small area of granulations on its interior side distally $v s$. trochanter with granulations, femur with a large area of granulations on its interior and dorsal sides, chela with a small area of granulations on its interior side distally in F $R$. diocletiani vs. trochanter with granulations, femur with a large area of granulations on its interior and dorsal sides, chela with a small area of granulations on its interior side distally/both on its exterior and interior sides in $\mathrm{M} \mathrm{F} \mathrm{R.} \mathrm{italicus} \mathrm{vs.}$ pedipalps mostly smooth, only a few inconspicuous tubercles borne on interior side of femur in F $R$. trojanicus $v s$. trochanter with no granulations, femur with a very small area of granulations on its interior side medially, chela with a very small area of granulations on its interior side distally in $\mathrm{M} \mathrm{F} R$. almissae vs. trochanter with no granulations, femur with a small area of granulations on its interior side distally, chela with a large area of granulations on both its exterior and interior sides and dorsally in $\mathrm{M} R$. ladestani $v$ s. trochanter with no granulations, femur with a very small area of granulations on its interior side medially/a large area of granulations both interiorly and dorsally, chela with a very small area of granulations on both its exterior and interior sides/interior side distally in M F $R$. navalia); number of setae on opisthosomal sternites $\mathrm{V}-\mathrm{X}$ (13/14-15/1614/16-14/15-14/14-13/12 in $\mathrm{H} \mathrm{F}$ and $\mathrm{P} F$, respectively $v s$. 16-14-13-12-12-11 in $\mathrm{F} R$. diocletiani vs. 16-17-15-15-1413 in F $R$. trojanicus vs. 15/11-16/10-15/11-15/11-15/11$13 / 10$ in $\mathrm{P} \mathrm{F}$ and $\mathrm{H} \mathrm{M} R$. almissae, respectively vs. 16-1515-13-11-11 in M R. ladestani); as well as in a number of other linear measurements and morphometric ratios (Fig. 1; Table 1) [Simon, 1896; Beier, 1963; Gardini, Rizzerio, 1985; Ćurčić, 1988; Ozimec, 2004; Ćurčić et al., 2008, 2010, 2012e, 2013c, 2021].

Key to the species of Roncus from Croatia (Fig. 2; TABle 1) (MODified AFTer Beier [1963])

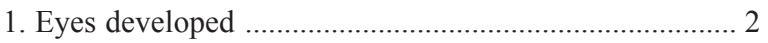
- Eyes absent ...................................................................... 9

2. Several microsetae present proximal to trichobothria $e b$ and $e s b$, widely distributed species .............. R. lubricus

- No microsetae present proximal to trichobothria $e b$ and $e s b$, locally distributed species ..................................... 3

3. Pedipalpal femur densely granulated .............................. 4

- Pedipalpal femur weakly granulated ................................... 5

4. Total body length $3.115 \mathrm{~mm}$, ratio of length of pedipalpal chelal palm to breadth of pedipalpal chela 1.47 , length of pedipalpal chelal finger $0.65 \mathrm{~mm}$....... R. diocletiani

- Total body length $2.35-2.50 \mathrm{~mm}$, ratio of length of pedipalpal chelal palm to breadth of pedipalpal chela 1.60 1.73 , length of pedipalpal chelal finger $0.76-0.85 \mathrm{~mm}$. R. italicus

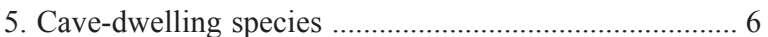

- Soil-dwelling species ........................................................ 8

6. Femur on average at least four times as long as broad, tibia of leg IV on average at least six times as long as broad ..................................................... R. trojanicus

- Femur on average less than four times as long as broad, tibia of leg IV on average less than six times as long as broad

7. Total body length $3.22 \mathrm{~mm}$, pedipalpal chela densely granulated, ratio of length to breadth of tibia of leg IV 4.625 . R. ladestani

- Total body length $2.30-2.975 \mathrm{~mm}$, pedipalpal chela weakly granulated, ratio of length to breadth of tibia of leg IV 4.83-5.23 R. navalia

8. Pedipalpal femur and chela with denser granulation, length of pedipalp with coxa $3.60-3.72 \mathrm{~mm}$, ratio of length to breadth of tarsus of leg IV 4.71-4.75 R. sutikvae sp.n.

- Pedipalpal femur and chela with less dense granulation, length of pedipalp with coxa $4.30-4.825 \mathrm{~mm}$, ratio of length to breadth of tarsus of leg IV 4.00-4.20. 
9. Distributed in somewhat larger area .............................. 10

- Inhabiting solely Croatia ................................................... 11

10. Pedipalpal chelal finger as long as pedipalpal chelal palm with stalk or shorter, distributed more southerly .. $R$. anophthalmus

- Pedipalpal chelal finger longer than pedipalpal chelal palm with stalk, distributed more northerly ........ R. stussineri

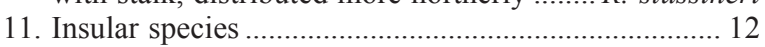

- Continental species ......................................................... 13

12. Length of pedipalp with coxa $6.645-7.79 \mathrm{~mm}$, ratio of length to breadth of pedipalpal tibia 2.99-3.33, inhabiting the island of Brač ................................. R. insularis

- Length of pedipalp with coxa $5.20 \mathrm{~mm}$, ratio of length to breadth of pedipalpal tibia 2.27, inhabiting the island of Mljet ......................................................... meledae

13. Epistome low, rounded ... 14

- Epistome tubercular, triangular ..................................... 16

14. Pedipalpal femur 4.35 times as long as broad, tibia of leg IV 7.07 times as long as broad, inhabiting middle Dal-

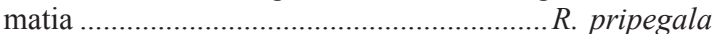

- Pedipalpal femur less than four times as long as broad, tibia of leg IV less than seven times as long as broad, inhabiting southern Dalmatia ..................................... 15

15. Total body length $4.04-4.11 \mathrm{~mm}$, ratio of length to breadth of pedipalpal femur 3.51-3.53, ratio of length to breadth of tibia of leg IV 5.96-6.19 ........... R. narentae

- Total body length $2.86 \mathrm{~mm}$, ratio of length to breadth of pedipalpal femur 3.89 , ratio of length to breadth of tibia of leg IV 5.75 ............................................ R. ragusae

16. Length of pedipalp with coxa $3.61 \mathrm{~mm}$, pedipalpal femur granulated, length of leg IV $2.455 \mathrm{~mm} \ldots . . . R$. argyrunti

- Length of pedipalp with coxa $6.11-6.34 \mathrm{~mm}$, pedipalpal femur not granulated, length of leg IV $3.975-4.07 \mathrm{~mm}$ R. podaga

\section{Discussion}

The type specimens of the new pseudoscorpion species were collected under stones in a sparse planted forest of Aleppo pine at the foot of a small rocky hill called Sutikva, which is situated in the village of Mravince in the environs of the town of Solin and the city of Split. Several more efforts were made to collect additional specimens of $R$. sutikvae sp.n., but they were unsuccessful. It can be therefore assumed that the taxon is probably rare. It is most likely epigean, as evidenced by the habitat at the type locality, as well as by the presence of a pair of eyes. This pseudoscorpion species is endemic to the Dinarides of central Dalmatia, similar to most of its closest relatives $(R$. diocletiani, $R$. trojanicus, and $R$. almissae) [Ćurčić, 1988; Ćurčić et al., 2008, 2010, 2013c]. Some of its related congeners inhabit certain Adriatic islands, namely Pag ( $R$. navalia) and Lastovo ( $R$. ladestani), situated in northern and southern Dalmatia, respectively [Ćurčić et al., 2012e, 2021]. In contrast, its relative $R$. italicus has a somewhat wider distribution and is known from the Alps of northwestern Italy and northwestern Slovenia, as well as from certain regions of Croatia (Istria and the environs of Zagreb) [Gardini, Rizzerio, 1985; Ćurčić, 1988; Ozimec, 2004].

Out of a total of 16 Roncus species from Croatia, the majority are blind and considered to be troglobitic
[R. anophthalmus (Ellingsen, 1910), R. argyrunti B. Curčić et Rađa, 2014, R. insularis Beier, 1938, $R$. meledae B. Ćurčić et Rađa, 2012, $R$. narentae Dimitrijević et Rađa, 2008, $R$. podaga B. Ćurčić, 1988, $R$. pripegala B. Ćurčić, 1988, R. ragusae B. Ćurčić, 2012, and R. stussineri (Simon, 1881)], while some are eyed and epigeic/endogeic in their lifestyle (R. almissae, $R$. diocletiani, $R$. italicus, $R$. lubricus, $R$. ladestani, $R$. navalia, and $R$. trojanicus) [Beier, 1963; Ćurčić, 1988; Ćurčić et al., 1992, 2008, 2010, 2012d, e, f, 2013c, 2014a, 2021; Dimitrijević, Rađa, 2008]. Of the Croatian eyed Roncus taxa, the last three are cave-dwelling (but probably also inhabit non-cave habitats in the vicinity of their type localities), while the remaining ones were found in soil or leaf litter. Two additional Roncus species are known to inhabit Croatia [Harvey, 2013], but they have now been transferred to the recently established genus Archaeoroncus B. Curčić et Rađa, 2012 [A. tenuis (Hadži, 1933) and A. dalmatinus (Hadži, 1933)], which currently comprises four species [Ćurčić et al., 2012a].

The ratios of some articles of appendages of pseudoscorpions can indicate their way of life. Epigean species have a small body, short appendages, and developed eyes, while cavernicolous pseudoscorpions have an enlarged body, elongated appendages (especially pedipalps), and no eyes. Zaragoza, Štáhlavský [2008] concluded that the tibia IV length to breadth ratio and pedipalpal femur length to breadth ratio in pseudoscorpions can be used to evaluate the degree of adaptation to their cave life. Average values of the tibia IV length to breadth ratio and pedipalpal femur length to breadth ratio of about 6.0 and 4.0, respectively, or higher point to a troglophilic/troglobitic state of a Roncus species, while lower values of these ratios indicate its epigean tendencies [Zaragoza, Št'áhlavský, 2008]. Values of the tibia IV length to breadth ratio of 4.855.64 suggest that $R$. sutikvae sp.n. has epigean affinities. Among other Croatian eyed Roncus species, only $R$. trojanicus displays troglophilic tendencies, to judge from its tibia IV length to breadth ratio of 6.06. In addition, in certain specimens of $R$. italicus, this ratio is higher than 6.0, indicating that this edaphobitic species could have some troglophilic tendencies. A pedipalpal femur length to breadth ratio of 3.39 points to epigean habits of $R$. sutikvae sp.n. Among other Croatian eyed Roncus species, this ratio has a somewhat greater value (4.20) only in $R$. trojanicus, confirming its troglophilic condition. Interestingly, one of two type specimens of $R$. navalia exhibits troglophilic tendencies as well, this ratio being 4.72 in it. Generally, only a few Croatian eyed Roncus species ( $R$. sutikvae sp.n., $R$. diocletiani, $R$. italicus, and $R$. navalia) share a very small body length and the presence of especially short appendages and their articles.

Based on their morphological features, two main complexes of species of the genus Roncus inhabiting Croatia can be recognized: (i) a complex of blind cavedwelling species ( $R$. anophthalmus, $R$. argyrunti, $R$. insularis, $R$. meledae, $R$. narentae, $R$. podaga, $R$. prip- 
egala, $R$. ragusae, and $R$. stussineri); and (ii) a complex of eyed species living in different habitats (leaf litter, soil, caves) ( $R$. almissae, $R$. diocletiani, $R$. italicus, $R$. ladestani, $R$. lubricus, $R$. navalia, $R$. sutikvae sp.n., and $R$. trojanicus). Within the first complex, only two species have a somewhat larger distribution $(R$. stussineri and $R$. anophthalmus), while the remaining inhabit the Dinarides or Dalmatian islands and are endemic to Croatia. According to Zaragoza, Št'áhlavský [2008], out of those, four species ( $R$. insularis, $R$. podaga, $R$. pripegala, and $R$. stussineri) can be considered as true trogobites (ratio of length to breadth of pedipalpal femur $>4$, ratio of length to breadth of tibia of leg IV $>6$ ), two ( $R$. meledae and $R$. narentae) can be treated as troglophiles (ratio of length to breadth of pedipalpal femur $<4$, ratio of length to breadth of tibia of leg IV > 6), while three ( $R$. anophthalmus, $R$. argyrunti, and $R$. ragusae), in spite of being blind, have epigean tendencies (ratio of length to breadth of pedipalpal femur $<4$, ratio of length to breadth of tibia of leg IV < 6). The taxa belonging to the two latter categories can likely be found out of caves (probably in deep soil in the surrounding areas). In regard to the complex of eyed Roncus species from Croatia, two groups are identified based on the presence/absence of microsetae proximal to trichobothria $e b$ and $e s b$ : (i) the group of $R$. lubricus (with a few microsetae proximal to $e b$ and $e s b$ ); and (ii) the group of all other Croatian eyed Roncus species (with no microsetae proximal to $e b$ and $e s b$ ). Within the second group, the pedipalpal femur is densely granulated in $R$. diocletiani and $R$. italicus, whereas it is weakly granulated in the remaining taxa of the group. Some of the latter taxa live in leaf litter and soil, others inhabit caves, but almost all $(R$. almissae, $R$. ladestani, $R$. navalia, and $R$. sutikvae sp.n.) exhibit epigean tendencies (only $R$. trojanicus displays troglophilic affinities).

The new species and other Croatian eyed congeners probably share the same evolutionary lineage. The relationships of these and many other Balkan Roncus species are not clear and have yet to be determined [Mahnert, Gardini, 2014]. A number of Roncus taxa are separated from each other only morphologically and morphometrically. A multidisciplinary approach that utilizes several types of analyses (DNA barcoding, karyological studies, morphological characterization of structure of the genital apparatus) of rich samples of certain Roncus species needs to be taken to confirm the validity of such taxa and resolve their taxonomic status [Ćurčić et al., 2021].

The time of origin of each endemic Dinaric pseudoscorpion taxon is difficult to ascertain with precision. One can speculate about this only for the taxa with more primitive traits and disjunctive ranges. The origin and natural history of endemic soil-dwelling members of the genus Roncus inhabiting the Dinarides are not easy to determine, as these taxa represent an adaptive and selective fauna [Ćurčić, 1988; Curčić et al., 2013c]. The colonization of epigean and hypogean habitats (including soil and caves) in the region passed through successive stages over different geological periods [Ćurčić, 1988]. The Dinarides were most likely colonized at the beginning of their existence by a number of lineages of Roncus that already inhabited the Mediterranean forests, lineages whose survival has been sustained by continuity of the continental phase, relative constancy of life conditions in the soil and in caves, and isolation of the underground habitats [Guéorguiev, 1977; Deeleman-Reinhold, 1978; Ćurčić, 1988; Curčić et al., 2004].

According to Guéorguiev [1977], different representatives of Roncus originated or lived in regions (including the Dinarides) and geological epochs with a humid and warm climate, inhabiting leaf litter and humus. With increasing aridity and formation of different underground niches in the Dinarides, old lineages of Roncus (thermophilous and hygrophilous representatives) found shelter in the underground domain (humus, soil, caves), from which some taxa (including the new pseudoscorpion species) evolved as cave- and soildwelling inhabitants [Ćurčić, Dimitrijević, 2007]. One of the adjusting responses of both humicolous and epigean pseudoscorpion taxa to survive in conditions of a Mediterranean climate is their adaptation to inhabit soil, caves, and pits [Ćurčić, 1986, 1988].

The high diversity of pseudoscorpions [Ćurčić et al., 2004] and related arachnid groups [Deltshev, 2004] on the Balkan Peninsula highlights the fact that the region represents a glacial refugium [Schmitt, 2007], a place of origin of endemics and relicts and a zone of faunal exchange [Murienne et al., 2010]. Such great diversity can be explained by the peninsula's complex and long palaeogeographic history [Parmakelis et al., 2006], as well as by its high habitat variety, striking topographic heterogeneity, and great climatic variations [Murienne et al., 2010].

Acknowledgements. We are grateful to Mr. Raymond Dooley (Belgrade, Serbia), who kindly edited the English text of the manuscript. We would also like to thank Dr. Kirill Mikhailov (Zoological Museum of the Moscow State University, Moscow, Russia) for his comments and constructive criticism of the manuscript. This study was financially supported by the Serbian Ministry of Education, Science and Technological Development (Contracts Nos. 45103-68/2020-14/200178 and 451-03-68/2020-14/200172).

\section{References}

Beier M. 1963. Ordnung Pseudoscorpionidea (Afterskorpione) // Bestimmungsbücher zur Bodenfauna Europas. Lieferung 1. Berlin: Akademie-Verlag. $313 \mathrm{~S}$.

Christophoryová J., Červená M., Krajčovičová K. 2018. Confirmed record of the genus Chernes in Bosnia and Herzegovina (Pseudoscorpiones: Chernetidae) // Natura Croatica. Vol.27. No.1. P.233-237.

Christophoryová J., Jablonski D. 2017. New data concerning the distribution of pseudoscorpions in Albania (Pseudoscorpiones: Chernetidae) // Natura Croatica. Vol.26. No.1. P.117-122.

Ćurčić B.P.M. 1986. On the origin and biogeography of some pseudoscorpions of the Balkan Peninsula // Biologia GalloHellenica. Vol.12. P.85-92. 
Ćurčić B.P.M. 1988. Cave-Dwelling Pseudoscorpions of the Dinaric Karst. Classis IV: Historia Naturalis, Opera 26, Institutum Biologicum Ioannis Hadži 8. Ljubljana: Academia Scientiarum et Artium Slovenica. $192 \mathrm{p}$.

Ćurčić B.P.M. 1992. New and little-known pseudoscorpions of the genus Roncus L. Koch (Neobisiidae, Pseudoscorpiones) from Serbia, Yugoslavia // Bijdragen tot de Dierkunde. Vol.61. No.4. P.237-249.

Ćurčić B.P.M., Dimitrijević R.N. 2007. Roncus travuniensis sp. n. (Neobisiidae, Pseudoscorpiones), a troglobitic false scorpion from Bosnia-Herzegovina // Biologia, Bratislava. Vol.62. No.1. P.84-87.

Ćurčić B.P.M., Dimitrijević R.N., Karamata O.S. 1992. A revision of some species of Roncus L. Koch (Neobisiidae, Pseudoscorpiones) from North America and South Europe // The Journal of Arachnology. Vol.20. No.2. P.114-128.

Ćurčić B.P.M., Dimitrijević R.N., Legakis A. 2004. The Pseudoscorpions of Serbia, Montenegro, and the Republic of Macedonia // Monographs, Institute of Zoology. Belgrade-Athens: Institute of Zoology, Faculty of Biology, University of Belgrade; Hellenic Zoological Society; Committee for Karst and Speleology, Serbian Academy of Sciences and Arts \& Institute of Nature Conservation of the Republic of Serbia. Vol.8. 400 p.

Ćurčić B.P.M., Dimitrijević R.N., Rađa T., Makarov S.E., Ilić B.S. 2012a. Archaeoroncus, a new genus of pseudoscorpions from Croatia (Pseudoscorpiones, Neobisiidae), with descriptions of two new species // Acta zoologica bulgarica. Vol.64. No.4. P.333-340.

Ćurčić B.P.M., Dimitrijević R.N., Rađa T., Milinčić M. 2012b. Chthonius (Chthonius) makirina (Chthoniidae, Pseudoscorpiones), a new species from Croatia // Archives of Biological Sciences, Belgrade. Vol.64. No.2. P.709-714.

Ćurčić B.P.M., Dimitrijević R.N., Rađa T., Rađa B. 2008. On two new species of pseudoscorpions from the Dinaric Karst // Archives of Biological Sciences, Belgrade. Vol.60. No.2. P.315324.

Ćurčić B.P.M., Makarov S.E., Ćurčić S.B., Rađa T., Tomić V.T., Ilić B.S. 2012c. A new rare representative of Microchthonius Hadži (Chthoniidae, Pseudoscorpiones) from Dalmatia, Croatia // Acta zoologica bulgarica. Vol.64. No.3. P.229-234.

Ćurčić B.P.M., Makarov S.E., Rađa T., Ilić B.S., Antić D.Ž. 2012d. Roncus meledae n. sp. and Neobisium oculatum n. sp., from the Island of Mljet, Dalmatia (Neobisiidae, Pseudoscorpiones) // Archives of Biological Sciences, Belgrade. Vol.64. No.4. P.1567-1576.

Ćurčić B.P.M., Rađa T., Ćurčić S.B., Ćurčić N.B. 2010. On Roncus almissae n. sp., $R$. krupanjensis n. sp., and $R$. radji n. sp., three new pseudoscorpions (Pseudoscorpiones, Neobisiidae) from Croatia and Serbia, respectively // Archives of Biological Sciences, Belgrade. Vol.62. No.2. P.503-513.

Ćurčić B.P.M., Rađa T., Ćurčić S.B., Ilić B.S., Tomić V.T., Makarov S.E. 2013a. Microchthonius elegantissimus n. sp., a new troglobitic pseudoscorpion (Pseudoscorpiones, Chthoniidae) from Croatia // Archives of Biological Sciences, Belgrade. Vol.65. No.1. P.405-410.

Ćurčić B.P.M., Rađa T., Dimitrijević R.N. 2012e. On two new cave pseudoscorpions, Chthonius (Chthonius) pagus n. sp. (Chthoniidae) and Roncus navalia n. sp. (Neobisiidae), from the Island of Pag, Croatia // Archives of Biological Sciences, Belgrade. Vol.64. No.4. P.1555-1565.

Ćurčić B.P.M., Rađa T., Dimitrijević R.N., Curčić N.B., Ćurčić S.B. 2021. Roncus ladestani $\mathrm{n}$. sp. and R. pecmliniensis n. sp., two new pseudoscorpions (Pseudoscorpiones, Neobisiidae) from Croatia and Bosnia and Herzegovina, respectively // Zoologichesky Zhurnal. Vol.100. No.2. P.159-169.

Ćurčić B.P.M., Rađa T., Dimitrijević R.N., Ćurčić S.B. 2012f. On two new cave pseudoscorpions from Dalmatia (Croatia) (Chthoniidae and Neobisiidae, Pseudoscorpiones) // Archives of Biological Sciences, Belgrade. Vol.64. No.3. P.1099-1108.

Ćurčić B.P.M., Rađa T., Dimitrijević R.N., Curčić S.B., Curčić N.B., Makarov S.E. 2013b. A new cave pseudoscorpion from Dalmatia - Microchthonius tragurion n. sp. (Chthoniidae, Pseu- doscorpiones) // Archives of Biological Sciences, Belgrade. Vol.65. No.3. P.1253-1259.

Ćurčić B.P.M., Rađa T., Dimitrijević R.N., Ćurčić S.B., Ćurčić N.B., Makarov S.E. 2014a. On two new cave species of pseudoscorpions (Neobisiidae, Pseudoscorpiones) from Herzegovina and Dalmatia // Archives of Biological Sciences, Belgrade. Vol.66. No.1. P.377-384.

Ćurčić B.P.M., Rađa T., Dimitrijević R.N., Ćurčić S.B., Ćurčić N.B., Makarov S.E., Ilić B.S. 2014b. Microchthonius kasteli n. sp. (Chthoniidae, Pseudoscorpiones) - a new cave false scorpion from Croatia (Dalmatia) // Archives of Biological Sciences, Belgrade. Vol.66. No.1. P.437-443.

Ćurčić B., Rađa T., Dimitrijević R., Vesović N., Ćurčić S. 2015. On two new species of Microchthonius Hadži (Pseudoscorpiones, Chthoniidae) from Dalmatia, Croatia // Universiteti i Shkodrës „Luigj Gurakuqi““, Buletin Shkencor, Seria e Shkencave të Natyrës. Vol.65. P.80-93.

Ćurčić B.P.M., Rađa T., Makarov S.E., Dimitrijević R.N., Ćurčić S.B., Ilić B.S. 2013c. On the identity of types of Roncus diocletiani Ćurčić, Dimitrijević \& Rađa and Archaeoroncus tenuis (Hadži) (Pseudoscorpiones, Neobisiidae) from Croatia // Archives of Biological Sciences, Belgrade. Vol.65. No.2. P.761766.

Ćurčić B.P.M., Rađa T., Rađa B., Dimitrijević R.N., Tomić V.T., Ilić B.S. 2013d. A new cave pseudoscorpion from the Adriatic Isle of Šolta (Dalmatia): Microchthonius solentanus n. $\mathrm{sp}$. (Pseudoscorpiones: Chthoniidae) // Acta zoologica bulgarica. Vol.65. No.3. P.283-288.

Ćurčić N.B., Dimitrijević R.N. 2016. Checklist of the pseudoscorpions (Arachnida: Pseudoscorpiones) of Montenegro // Ecologica Montenegrina. Vol.7. P.439-450.

Ćurčić N.B., Dimitrijević R.N., Curčić S.B. 2020. Checklist of the pseudoscorpions (Arachnida: Pseudoscorpiones) of Serbia // Arthropoda Selecta. Vol.29. No.1. P.13-27.

Deeleman-Reinhold C.L. 1978. Revision of the Cave-Dwelling and Related Spiders of the Genus Troglohyphantes Joseph (Linyphiidae), With Special Reference to the Yugoslav Species. Classis IV: Historia Naturalis, Opera 23, Institutum Biologicum Ioannis Hadži 6. Ljubljana: Academia Scientiarum et Artium Slovenica. $221 \mathrm{p}$.

Deltshev C. 2004. A zoogeographical review of the spiders (Araneae) of the Balkan Peninsula // Griffiths H.I., Kryštufek B., Reed J.M. (eds.). Balkan Biodiversity: Pattern and Process in the European Hotspot. Dordrecht: Kluwer Academic Publishers. P.193-200.

Dimitrijević R.N., Rađa T. 2008. On two new pseudoscorpions (Pseudoscorpiones, Arachnida) from Dalmatia (Croatia) // Makarov S.E., Dimitrijević R.N. (eds.). Advances in Arachnology and Developmental Biology. Papers Dedicated to Prof. Dr. Božidar Ćurčić. Monographs, Volume 12, Institute of Zoology. Vienna-Belgrade-Sofia: Institute of Zoology, Faculty of Biology, University of Belgrade; Committee for Karst and Speleology, Serbian Academy of Sciences and Arts; Institute of Zoology, Bulgarian Academy of Sciences; Faculty of Life Sciences, University of Vienna \& UNESCO MAB Committee of Serbia. P.259-266.

Dimitrijević R.N., Rađa T. 2016. On the biodiversity of pseudoscorpions in Croatia: Neobisium curcici (Pseudoscorpiones: Neobisiidae), a new cave-dwelling species from Dalmatia (Croatia) // Ecologica Montenegrina. Vol.7. P.259-265.

Gabbutt P.D., Vachon M. 1967. The external morphology and life history of the pseudoscorpion Roncus lubricus // Journal of Zoology. Vol.153. No.4. P.475-498.

Gardini G. 1982. Pseudoscorpioni cavernicoli sardi. II. Neobisiidae e Chernetidae, con considerazioni sui Neobisiinae cavernicoli (Pseudoscorpioni d'Italia, XII) // Fragmenta Entomologica. Vol.16. No.2. P.89-115.

Gardini G. 1983. Redescription of Roncus lubricus L. Koch, 1873, type-species of the genus Roncus L. Koch, 1873 (Pseudoscorpionida, Neobisiidae) // Bulletin of the British Arachnological Society. Vol.6. Pt.2. P.78-82.

Gardini G. 2000. Catalogo degli Pseudoscorpioni d'Italia (Arachnida) // Fragmenta Entomologica. Vol.32 (Suppl.). P.1-181. 
Gardini G., Rizzerio R. 1985. Materiali per una revisione del genere Roncus L. Koch, 1873. I. Ridescrizione dei tipi di alcune specie italiane non cavernicole (Pseudoscorpionida, Neobisiidae) // Fragmenta Entomologica. Vol.18. No.1. P.47-79.

Gardini G., Rizzerio R. 1986. Materiali per una revisione del genere Roncus L. Koch, 1873. II. Ridescrizione dei tipi delle specie parablothroidi alpine e appenniniche // Fragmenta Entomologica. Vol.19. No.1. P.1-56.

Gardini G., Rizzerio R. 1987. I Roncus eucavernicoli del gruppo siculus (Pseudoscorpionida Neobisiidae) // Bollettino della Società Entomologica Italiana. Vol.119. No.2. P.67-80.

Guéorguiev V.B. 1977. La faune troglobie terrestre de la péninsule Balkanique. Origine, formation et zoogéographie. Special Edition. Sofia: Bulgarian Academy of Sciences. 182 p.

Harvey M.S. 2013. Pseudoscorpions of the World. Version 3.0 Western Australian Museum, Perth, online at: http://www. museum.wa.gov.au/catalogues/pseudoscorpions (accessed on 23 December 2020).

Henderickx H., Zaragoza J.A. 2005. Notes on Roncus (Pseudoscorpiones: Neobisiidae) from the Eastern Pyrenees: new synonymy and description of a new species // Revista Ibérica de Aracnología. Vol.11. P.47-59.

Henderickx H., Zaragoza J.A. 2009. Roncus elbulli (Arachnida, Pseudoscorpiones), a new species from Cap de Creus Nature Park (Catalonia, Spain), with a key to the Spanish species of the genus Roncus // ZooKeys. Vol.8. P.19-34.

Latifi Z., Nassirkhani M., Mirshamsi O. 2020. A new epigean pseudoscorpion species (Pseudoscorpiones: Neobisiidae) from northeast of Iran, with an identification key to the species of the family Neobisiidae from Iran // Turkish Journal of Zoology. Vol.44. No.3. P. 230-237.

Mahnert V., Gardini G. 2014. Cave-inhabiting pseudoscorpion species of the genus Roncus (Pseudoscorpiones: Neobisiidae) from western Greece, including the Ionian Islands // Arachnologische Mitteilungen. Bd.48. P.28-37.

Murienne J., Karaman I., Giribet G. 2010. Explosive evolution of an ancient group of Cyphophthalmi (Arachnida: Opiliones) in the Balkan Peninsula // Journal of Biogeography. Vol.37. No.1. P.90-102.

Novák J., Jablonski D., Christophoryová J. 2019. Contribution to the pseudoscorpion fauna of Transylvania and the Eastern and Southern Carpathians, Romania (Arachnida: Pseudoscorpiones) // North-Western Journal of Zoology. Vol.15. No.2. P.127-134.

Ozimec R. 2004. List of Croatian pseudoscorpion fauna (Arachnida, Pseudoscorpiones) // Natura Croatica. Vol.13. No.4. P.381394.

Parmakelis A., Stathi I., Chatzaki M., Simaiakis S., Spanos L., Louis C. 2006. Evolution of Mesobuthus gibbosus (Brullé, 1832) (Scorpiones: Buthidae) in the northeastern Mediterranean region // Molecular Ecology. Vol.15. No.10. P.2883-2894.

Schmitt T. 2007. Molecular biogeography of Europe: Pleistocene cycles and postglacial trends // Frontiers in Zoology. Vol.4. P.11.

Simon E. 1896. Note sur quelques Chernetes de Ligurie // Annali del Museo civico di storia naturale di Genova, Serie 2a. Vol.16. No.36. P.372-376.

Zaragoza J.A., de Mas E., Ribera C. 2007. Pseudoescorpiones del Parque Natural del Cadí-Moixeró (Pirineo Catalán): estudio ecológico, faunístico y taxonómico (Arachnida: Pseudoscorpiones) // Revista Ibérica de Aracnología. Vol.14. P.69-95.

Zaragoza J.A., Št’áhlavský F. 2008. A new Roncus species (Pseudoscorpiones: Neobisiidae) from Montseny Natural Park (Catalonia, Spain), with remarks on karyology // Zootaxa. Vol.1693. No.1. P.27-40.

Responsible editor S.I. Golovatch 